\title{
Uwarunkowania dla jazdy tego samego zestawu kołowego po torze kolejowym i tramwajowym (1)
}

\begin{abstract}
$W$ artykule dokonano wszechstronnej analizy technicznej problemów, jakie napotkałby ten sam zestaw kołowy podczas jazdy pojazdu zarówno po torach kolejowych jak i po torach tramwajowych $w$ Polsce. Wykazano, ze przy określonych uwarunkowaniach taka jazda jest możliwa, co oznacza realność zbudowania pojazdu tramwajowo-kolejowego.
\end{abstract}

\section{Wstęp}

W ostatnich latach $\mathrm{w}$ polskiej prasie technicznej $[1,2$, 3 i 4$]$ ukazało się szereg artykułów proponujących sprzegnięcie regionalnego kolejowego systemu komunikacyjnego z systemem tramwajowym. Oznacza to zbudowanie pojazdów tramwajowo-kolejowych, które w miastach będących ośrodkami regionalnymi jeździłyby po torach tramwajowych zbudowanych $\mathrm{z}$ szyn tramwajowych zatopionych w jezdniach ulic lub ułożonych na wydzielonych torowiskach, a na przedmieściach wjeżdżałyby na tory kolejowe zbudowane $\mathrm{z}$ szyn kolejowych i po tych torach kontynuowałyby jazdę do miejscowości satelitarnych, znajdujących się w pobliżu danego centrum regionalnego.

Pojawiły się różne nazwy tego rodzaju pojazdów (np. w Krakowie byłby to TRAMKOL, w Poznaniu TRAMPER itp.).

W niniejszym artykule taki pojazd nazwano ,tramkol". Autorzy wym. publikacji dokonują obliczeń naprężeń w kole i w szynie a nawet proponują zastosowanie zestawów kołowych o zmiennym rozstawie kół.

Jest zatem celowe rozpatrzenie szeregu szczegółów technicznych związanych $\mathrm{z}$ jazdą i dokonanie analizy możliwości przejazdu tego samego zestawu kołowego po torze kolejowym i tramwajowym i danie odpowiedzi na pytanie, czy taki przejazd jest możliwy i przy jakich uwarunkowaniach.

W artykule rozpatrzono wszechstronnie poszczególne przypadki współpracy zestawu kołowego z torem, a mianowicie:

a) jazda po prostych torach kolejowych i tramwajowych,

b) jazda po łukach torów,

c) jazda po zwrotnicach,

d) jazda po kolejowych krzyżownicach rozwartokątnych.

\section{Jazda po torach prostych}

\subsection{Istniejące tory}

\subsubsection{Tor zbudowany z szyn kolejowych}

W Polsce istnieją dwa typu szyn kolejowych: S49 i UIC60 [5]. W artykule rozpatrzono typ UIC60.
Szyna kolejowa jest zawsze układana $\mathrm{w}$ torze pod pewnym kątem odchylenia jej osi symetrii od pionu $(\gamma)$.W świecie występują dwie różne wartości tego kąta: 1:20 oraz 1:40. W Polsce stosuje się wartość $\gamma$ $=1: 40$, ale na niektórych torach zbudowanych przed rokiem 1956 wysteppuje kąt $\gamma=1: 20$. W artykule przyjęto wartość $\gamma=1: 40$ lub 1:20, jeżeli wzajemne położenie koła i szyny jest mniej korzystne. Wymiary toru są określone przepisami D1 [10].

\subsubsection{Tor zbudowany z szyn tramwajowych}

W Polsce istnieją 2 typy szyn tramwajowych [9]:

- typ $180 \mathrm{~S}$ z obniżoną prowadnicą, stosowany przed rokiem 1992 głównie do budowy torów prostych

- typ $180 \mathrm{P}$ z podwyższoną prowadnicą, stosowany przed rokiem 1992 głównie do budowy łuków torów, a obecnie do budowy torów prostych i łukowych.

W artykule rozpatrzono typ 180S jako mniej korzystny. Szyny układa się w torze pionowo.

\subsection{Współpraca zestawu kołowego $\mathrm{z}$ torem}

\subsubsection{Wspótpraca kolejowego zestawu kolowego $z$} torem zbudowanym z szyn kolejowych

W Europie wymiary profilu bieżni koła kolejowego są jednakowe i określone przepisami karty UIC 510-2 [6]. Współpraca takiego zestawu kołowego $\mathrm{z}$ torem zbudowanym z szyn kolejowych jest przedstawiona na rys.1. Tolerancje podane na tym rysunku są tolerancjami eksploatacyjnymi, przy czym dopuszczalne graniczne zużycie szerokości prowadnej „d" nie jest sumą dopuszczalnych granicznych zużyć grubości „b” obu obrzeży kół. Jest to wymiar niezależny.

Podobnie dla toru kolejowego dopuszczalne graniczne zużycie prześwitu „A” nie jest sumą dopuszczalnych granicznych zużyć szerokości „F” obu główek szyn. Jest to również wymiar niezależny.

$\mathrm{Na}$ nowym kole kąt nachylenia tworzącej zewnętrznej części bieżni koła do poziomu ( $\varepsilon$ ) musi być zawsze większy niż kąt odchylenia osi symetrii od pionu $\gamma$. 


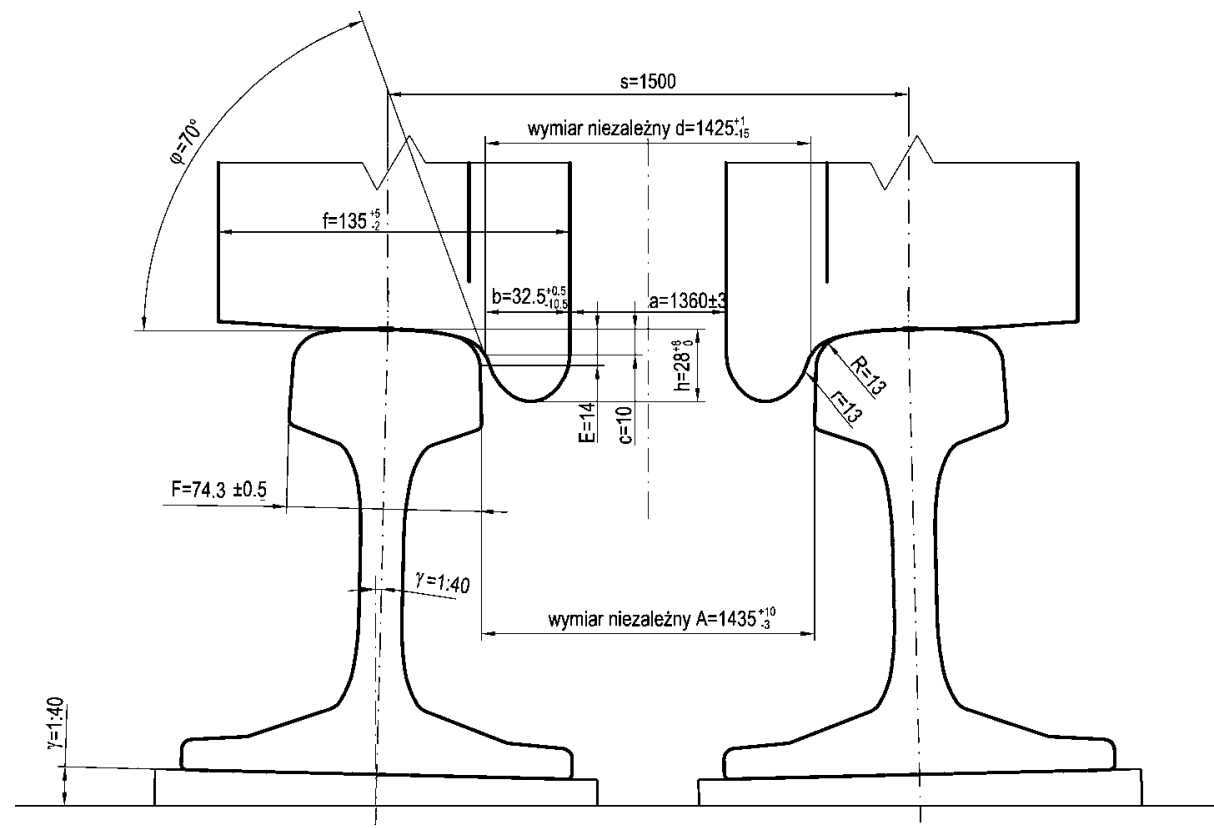

Rys.1. Kolejowy zestaw kołowy na prostym torze zbudowanym z szyn kolejowych

\subsubsection{Wspótpraca tramwajo- wego zestawu kolowe- go $z$ torem zbudowa- nym z szyn kolejowych}

W Polsce wymiary profilu bieżni kół tramwajowych są określone normą PN-91/K88251 [7]. Współpraca takiego zestawu kołowego z torem zbudowanym $\mathrm{z}$ szyn kolejowych jest przestawiona na rys. 2 . Tolerancje podane na tym rysunku są tolerancjami eksploatacyjnymi.

Dla tramwajowego zestawu kołowego dopuszczalne zużycie szerokości prowadnej „d” jest sumą dopuszczalnych zużyć grubości „b” obu obrzeży. Tolerancje eksploatacyjne toru są identyczne jak na rys. 1 .

W karcie UIC 510-2 [6] postanowiono, że kąt nachylenia tworzącej wynosi $\varepsilon=1: 15$, a więc $\varepsilon>\gamma$.

Wieloletnia praktyka wykazała prawidłowość wymiarów tej pary kinematycznej i współpraca zestawu kołowego $\mathrm{z}$ torem jest bardzo dobra.

W kole kolejowym, które zawsze toczy się swoją bieżnią po główce szyny, niezależnie od tego czy będzie to tor kolejowy prosty czy lukowy, czy zwrotnica kolejowa czy też kolejowa krzyżownica rozwartokątna, zużywa się tylko bieżnia koła, w wyniku czego maleje średnica toczna koła. Krag wierzchołkowy obrzeża koła nigdy nie toczy się po żadnym $\mathrm{z}$ elementów toru, wobec czego średnica wierzchołkowa obrzeża koła kolejowego pozostaje niezmienna. Zatem $\mathrm{w}$ miare przebiegu koła kolejowego wysokość obrzeża koła ulega zwiększeniu. Związek UIC ustalił, że największy dopuszczalny wzrost wysokości obrzeża koła kolejowego nie może przekraczać $8 \mathrm{~mm}$, aby obrzeże nie weszło w kolizję $\mathrm{z}$ łbami śrub mocujących szynę do podkładów (tolerancja eksploatacyjna wymiaru $h=28_{0}^{+8}$ ).

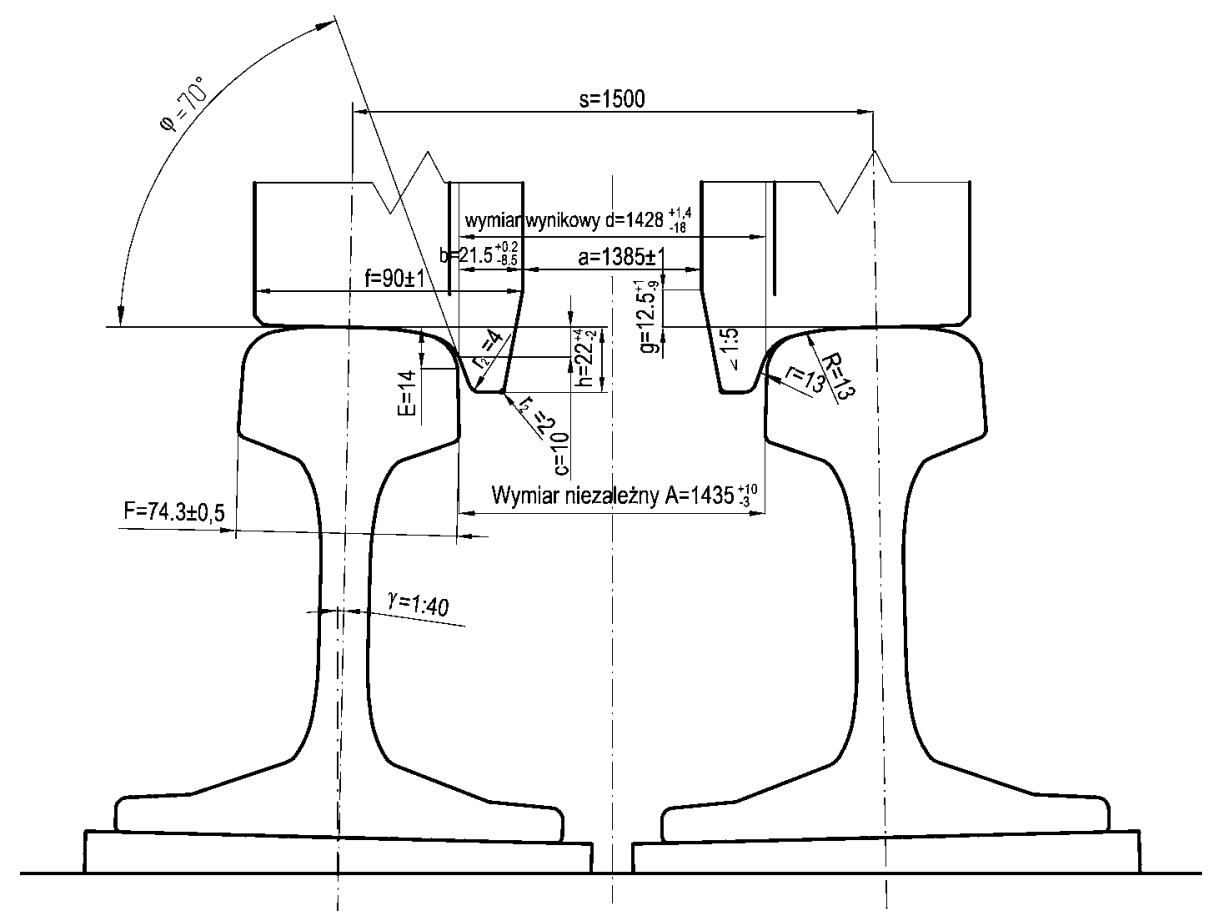

Rys.2. Tramwajowy zestaw kołowy na prostym torze zbudowanym z szyn kolejowych

Tolerancje eksploatacyjne wysokości obrzeża koła „h” w Polsce nie są ustalone. W Niemczech ustalono je na $\mathrm{h}=22_{-2}^{+4} \mathrm{~mm}[8]$. Tolerancje te są rozsądne i można przyjać takie same dla warunków polskich. 
Koło tramwajowe toczy się swoją bieżnią po główce szyny tylko na nowym torze prostym lub łukowym, ale nie $\mathrm{w}$ zwrotnicach i krzyżownicach tramwajowych. Na tych elementach toru koło toczy się kregiem wierzchołkowym swego obrzeża po dnach żłobków wykonanych w sercach zwrotnic i krzyżownicach tramwajowych.

Dlatego w kole tramwajowym zużyciu ulega i krag toczny i krag wierzchołkowy. Gdy jakieś koło biegnie przeważnie po torze prostym lub łukowym, a ilość zwrotnic i krzyżownic jest na trasie niewielka, to krąg toczny bieżni koła zużywa się szybciej niż krąg wierzchołkowy jego obrzeża.

Ale gdy ilość zwrotnic i krzyżownic na trasie jest duża albo gdy nacisk na oś jest bardzo duży, wówczas $\mathrm{krag}$ wierzchołkowy obrzeża koła zużywa się szybciej niż krag toczny bieżni koła. Wtedy wysokość obrzeża maleje w miarę przebiegu.

Ten przypadek współpracy nie wymaga analizowania, gdyż $\mathrm{w}$ wielu miastach w Polsce tory tramwajowe położone na wydzielonych torowiskach sa zbudowane z szyn kolejowych z tym, że serca zwrotnic i krzyżownic zawsze sa tramwajowe. $\mathrm{Na}$ podmiejskich liniach kursują tramwaje posiadające tramwajowe zestawy kołowe $\mathrm{i}$ komunikacja ta funkcjonuje nienagannie.

Jest to oczywiste $\mathrm{z}$ tego względu, że główne wymiary współpracy koła za szyną, a mianowicie:

- rozstęp nominalnych kręgów tocznych $(\mathrm{s}=1500$ $\mathrm{mm}$ )

- kąt nachylenia bieżni do poziomu na nominalnym kręgu tocznym $(\gamma=1: 40)$

- kąt nachylenia roboczego boku obrzeża koła $\left(\varphi=70^{\circ}\right)$

- położenie punktu atakującego koło $(\mathrm{c}=10 \mathrm{~mm})$

w tramwajowym zestawie kołowym są identyczne jak w kolejowym. Jedynie długość prowadna tramwajowego zestawu kołowego ( $d=1428_{-18}^{+1,4} \mathrm{~mm}$ jako wynikowa) jest nieco większa niż kolejowego zestawu kołowego $\left(d=1425_{-15}^{+1} \mathrm{~mm}\right)$ i luz poosiowy tramwajowego zestawu kołowego $\mathrm{W}$ torze zbudowanym $\mathrm{z}$ szyn kolejowych $\left(L=1435_{-3}^{+10}-1428_{-18}^{+1,4}=7_{-4,4}^{+28} \mathrm{~mm}\right)$ może być przy nowych kołach mniejszy ok. $3 \mathrm{~mm}$ niż luz kolejowego zestawu kołowego w tym samym torze
$\left(L=1435_{-3}^{+10}-1425_{-15}^{+1}=10_{-4}^{+25} \mathrm{~mm}\right), \quad$ ale przy prędkościach tramwajów nie przekraczających 75 $\mathrm{km} / \mathrm{h}$ nie ma to istotnego wpływu ani na spokojność biegu, ani na bezpieczeństwo jazdy.

\subsubsection{Wspótpraca tramwajowego zestawu kotowego z torem zbudowanym z szyn tramwajowych}

Wzajemne położenie kół i szyn pokazano na rys.3.

Tolerancje na rys. 3 są tolerancjami eksploatacyjnymi, przy czym dla toru tramwajowego dopuszczalne graniczne zużycie prześwitu toru A nie jest sumą dopuszczalnych granicznych zużyć szerokości główek F obu szyn. Jest to wymiar niezależny. Tolerancje eksploatacyjne tramwajowego zestawu kołowego są identyczne jak na rys. 2.

Ten przypadek współpracy również nie wymaga analizowania, gdyż we wszystkich miastach w Polsce tory tramwajowe zatopione $\mathrm{w}$ jezdniach ulic sa zbudowane $\mathrm{z}$ rowkowych szyn tramwajowych, a po nich toczą się znormalizowane tramwajowe zestawy kołowe i nie występują żadne nieprawidłowości we współpracy tej pary kinematycznej.

\subsubsection{Wspótpraca kolejowego zestawu kotowego z torem zbudowanym z szyn tramwajowych}

Rozpatrzono przypadek nowego kolejowego zestawu 
kołowego współpracującego $\mathrm{z}$ nowym torem zbudowanym z szyn tramwajowych (rys. 4).

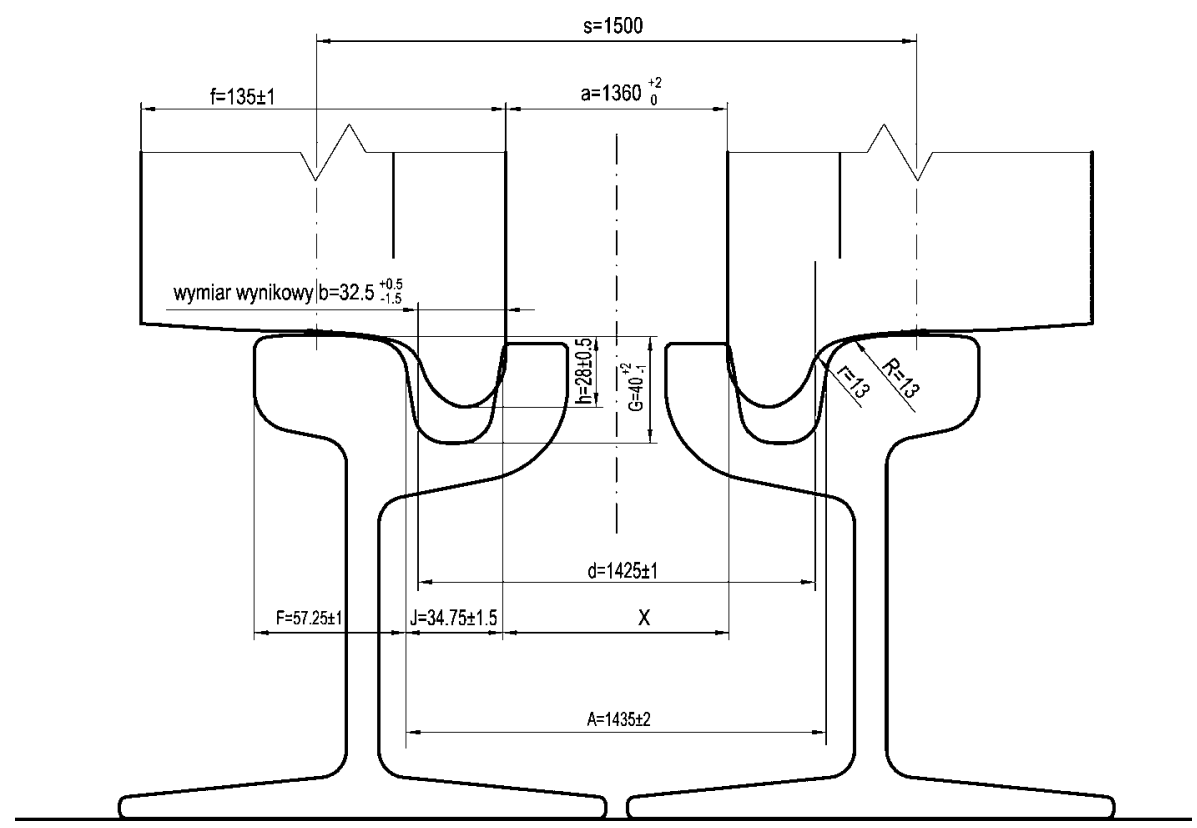

Rys.4. Kolejowy zestaw kołowy na prostym torze zbudowanym z szyn tramwajowych
Na niektórych łukach torów kolejowych, szczególnie tych zbudowanych przed kilkudziesięciu laty, prześwit toru jest poszerzony zgodnie $\mathrm{z}$ przepisami D1 [10] względem wartości nominalnej $1435 \mathrm{~mm}$, stosowanej na torze prostym. Ponadto na luku toru stosowana jest przechyłka tzn. szyna zewnętrzna jest podniesiona w stosunku do szyny wewnętrznej.

$\mathrm{W}$ miarę zużywania się toru poszerzony prześwit powiększa się coraz bardziej. W karcie UIC 505-1 [11] ustalono, że największy dopuszczalny prześwit toru na łuku może wynosić $\mathrm{A}=$ $1465 \mathrm{~mm}$.

Prowadzący zestaw kołowy przedniego wózka każdego pojazdu zawsze atakuje jednym kołem szynę zewnętrzną łuku, zajmując

Tolerancje na rysunku 4 są tolerancjami wykonawczymi, przy czym odchyłki wykonawcze grubości „b” każdego z obu obrzeży są wynikiem odchyłek wykonawczych szerokości prowadnej „d” i rozstawu czół wieńców kół „a”.

Kolejowy zestaw kołowy w ogóle nie pasuje do tı zbudowanego z szyn tramwajowych, gdyż rozst wewnętrznych krawędzi prowadnic rowków Sz wynosi:

$$
X=A-2 J=1435^{ \pm 2}-2 \cdot 34,75^{ \pm 1,5}=1365,5^{ \pm 5} \mathrm{~m}
$$

Nominalna wartość $X$ wynosi $1365,5 \mathrm{~mm}$, co j większe niż rozstaw wewnętrznych czół obrzeży kolejowego zestawu kołowego w stanie nowym, v noszący $a=1360_{-0}^{+2} \mathrm{~mm}$, a zatem przynajmniej j no obrzeże koła nowego zestawu kołowego nie $\mathrm{w}_{-}$, dzie $\mathrm{w}$ ogóle $\mathrm{w}$ rowek szyny i tym samym bieżnia tego koła nie spocznie na główce szyny i nie będzie mogła się w ogóle toczyć.

$\mathrm{Z}$ powyższego wynika wniosek, że kolejowy zestaw kołowy z zarysem wg PN nie może w ogóle jeździć po torach zbudowanych z szyn tramwajowych a tramkol musiałby posiadać zestawy kołowe o wymiarach wieńca jak dla tramwajowego zestawu kołowego.

\section{Jazda po łukach torów}

\subsection{Istniejące łuki torów}

\subsubsection{Luk toru kolejowego z poszerzonym prześwi- tem toru}

położenie w torze pokazane na rys. 5 . Tolerancje podane na tym rysunku są tolerancjami eksploatacyjnymi.

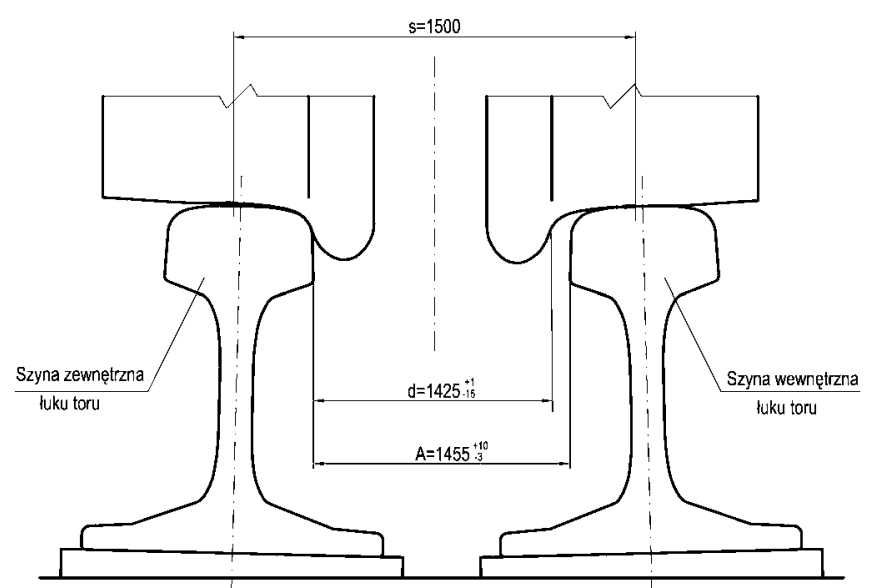

Rys.5. Nabieganie koła na szynę zewnętrzną łuku

\subsubsection{Luk toru tramwajowego}

Tor tramwajowy jest zbudowany bez powiększenia jego prześwitu na łuku. Wymiary główne toru i zestawu kołowego są identyczne jak w punktach 2.1.2 i 2.2.3.

\subsection{Wspólpraca zestawu kołowego $\mathrm{z}$ torem na luku}

3.2.1. Wspótpraca kolejowego zestawu kotowego z torem kolejowym na tuku o poszerzonym prześwicie toru 
Współpracę tę przedstawiono szkicowo na rysunku $6 \mathrm{i}$ uwzględniono kąt pochylenia szyny $\gamma=1: 20$ jako mniej korzystny.

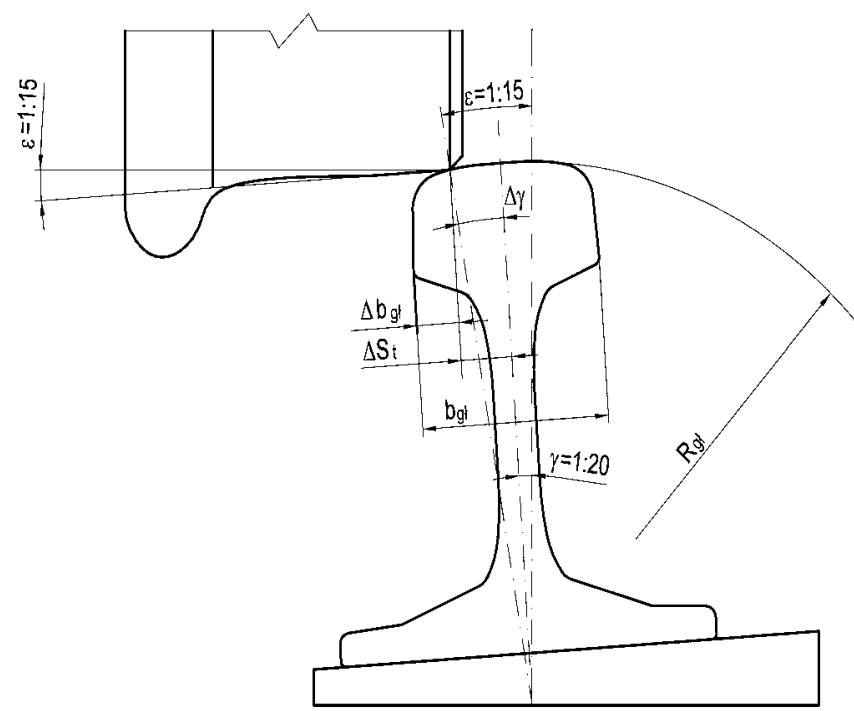

Rys.6. Współpraca zewnętrznej części bieżni koła z główką wewnętrznej szyny łuku podczas jazdy po łuku toru

Przyrost kąta $\gamma$ w punkcie styku koła z szyną wynosi:

$$
\Delta \gamma=\varepsilon-\gamma=\frac{1}{15}-\frac{1}{20}=\frac{4-3}{60}=\frac{1}{60}
$$

Odległość ścieżki toczenia (punktów styku) od osi symetrii szyny wynosi:

$$
\Delta S_{t}=R_{\mathrm{gt}} \cdot \sin \Delta \gamma \approx R_{\mathrm{gt}} \cdot \Delta \gamma
$$

Promień główki szyny wg PN-84/H-93421 [5] wynosi $\mathrm{R}_{\mathrm{gt}}=300 \mathrm{~mm}$.

Zatem

$$
\Delta S_{t}=300 \cdot \frac{1}{60}=5 \mathrm{~mm}
$$

Odległość ścieżki toczenia od krawędzi bocznej szyny wynosi:

$$
\Delta b_{g l}=\frac{b_{g l}}{2}-\Delta S_{t}
$$

gdzie $b_{\mathrm{g}}=$ szerokość główki szyny; dla szyny S49 wynosi ona wg PN-84/H-93421 [5] 70 $\mathrm{mm}$ a dla szyny $\mathrm{S} 60$ wynosi $74,3 \mathrm{~mm}$.

Ze względu na obliczenie minimalnej szerokości wieńca koła decydująca jest wartość większa tzn. 74,3 $\mathrm{mm}$

Zatem

$$
\Delta b_{\mathrm{gf}}=\frac{74,3}{2}-5=32,15 \approx 32 \mathrm{~mm} .
$$

Położenie koła na szynie wewnętrznej podczas przejazdu kolejowego zestawu kołowego po łuku o poszerzonym prześwicie toru pokazano na rys. 7 .

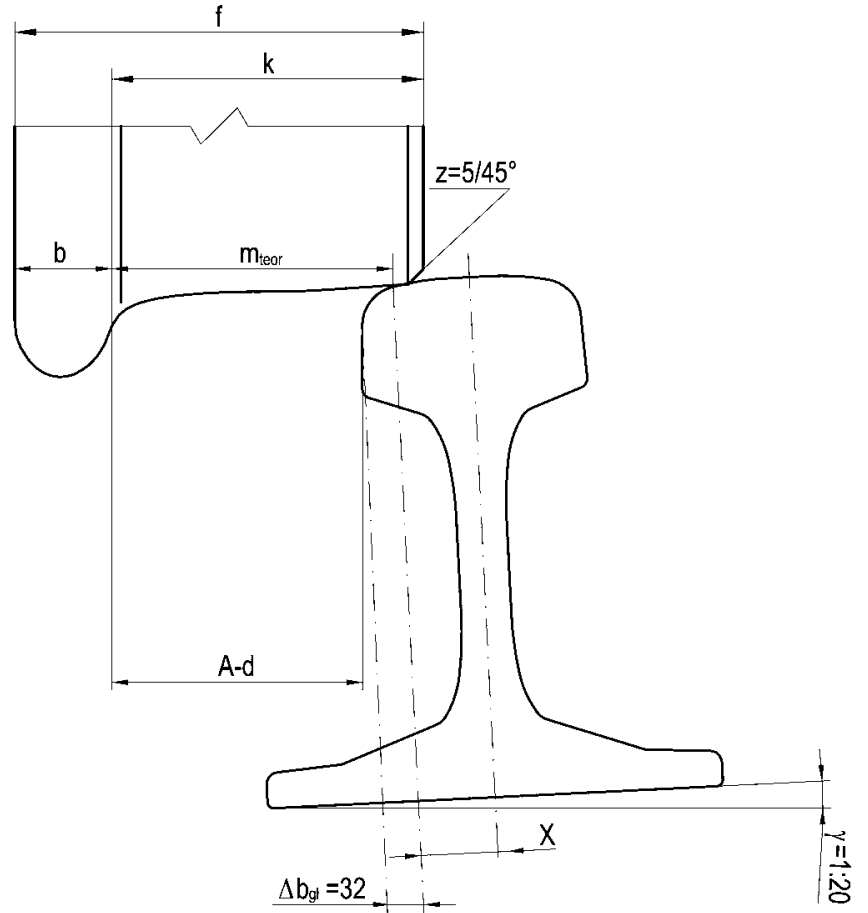

Rys. 7. Położenie koła na szynie wewnętrznej łuku

Istnieją następujące zależności wymiarowe:

$$
m_{\text {teor }}=A-d+\left(\Delta b_{g l}\right) \cdot \cos (\operatorname{arctg}(1: 20))
$$

Ponieważ

$$
\cos (\operatorname{arctg}(1: 20))=\cos 0,049958395 \approx 1 \text {, to }
$$

$$
m_{\text {teor }} \approx A-d+\Delta b_{g l}
$$

Szerokość obręczy koła

$$
f \geq b+m_{\text {teor }}+z, \text { czyli }
$$

$$
f \geq b+A-d+\Delta b_{g l}+z=A-(d-b)+\Delta b_{g l}+z
$$

Ale z rys. 1 wynika, że

$$
d-b=a+b
$$

Podstawiając (3) do (2) otrzyma się

$$
f \geq A-(a+b)+\Delta b_{g l}+z
$$

Największą wartość f otrzyma się, gdy:

- A będzie największe; $A=1455_{-3}^{+10}$, a zatem $\mathrm{A}_{\max }$ $=1465 \mathrm{~mm}$,

- $\quad \mathrm{a}+\mathrm{b}$ będzie najmniejsze;

$a+b=1360^{ \pm 3}+32,5_{-10,5}^{+0,5}=1392,5_{-13,5}^{+3,5}$,

a zatem $(\mathrm{a}+\mathrm{b})_{\min }=1379 \mathrm{~mm}$.

Wobec tego

$$
f \geq 1465-1379+32+5=123 \mathrm{~mm}
$$

Karta UIC 510-2 [6] zwiększa dla pewności ten wymiar, ustalając $f=135^{ \pm 1} \mathrm{~mm}$ (tolerancje wykonawcze), a tolerancje eksploatacyjne tego wymiaru wynoszą $f=135_{-2}^{+5} \mathrm{~mm}$. 


\subsubsection{Wspótpraca kolejowego zestawu kołowego z} torem kolejowym na luku bez poszerzenia prześwitu toru

Wszystkie obliczenia $\mathrm{z}$ punktu 3.2.1 są aktualne $\mathrm{z}$ tym, że $A=1435_{-3}^{+10} \mathrm{~mm}$ zamiast $1455_{-3}^{+10} \mathrm{~mm}$, a zatem $A_{\max }=1445 \mathrm{~mm}$, wobec czego ze wzoru (4) otrzyma się $f \geq 103 \mathrm{~mm}$. Ponieważ kolejowy zestaw kołowy musi mieć zdolność pokonywania zarówno łuków $\mathrm{z}$ poszerzeniem prześwitu toru jak $\mathrm{i}$ łuków bez poszerzenia prześwitu toru, to decyduje większa szerokość wieńca, czyli $f \geq 123 \mathrm{~mm}$.

Przyjęty w karcie UIC 510-2 [6] wymiar $f=135^{ \pm 1} \mathrm{~mm}$ spełnia to wymaganie.

Zatem przejazd kolejowego zestawu kołowego po łuku toru bez poszerzenia prześwitu jest w pełni możliwy.

\subsubsection{Przejazd kolejowego zestawu kolowego po luku toru zbudowanego z szyn tramwajo- wych}

Jak wynika $\mathrm{z}$ punktu 2.2.4. współpraca kolejowego zestawu kołowego na torze prostym zbudowanym $\mathrm{z}$ szyn tramwajowych jest niemożliwa i tym samym niemożliwy jest również przejazd kolejowego zestawu kołowego po łuku toru zbudowanego z szyn tramwajowych.

\subsubsection{Przejazd tramwajowego zestawu kolowego po tuku toru zbudowanego z szyn kolejowych bez poszerzenia prześwitu toru}

Dla tramwajowych zestawów kołowych zgodnie z rys. 2, $a=1385^{ \pm 1} \mathrm{~mm}, \quad b=21,5_{-8,5}^{+0,2} \mathrm{~mm}$ oraz prześwit toru $A=1435_{-3}^{+10} \mathrm{~mm}$.

Z wzoru (4) otrzyma się:

$$
\begin{aligned}
& f \geq A_{\max }-\left(a_{\min }+b_{\min }\right)+\Delta b_{g l}+z=1445-(1384+13)+ \\
& +32+5=85 \\
& \text { czyli } \quad f \geq 85 \mathrm{~mm} .
\end{aligned}
$$

Przyjęto dla pewności $f=90^{ \pm 1} \mathrm{~mm}$ i taka jest szerokość obręczy kół tramwajowych. Wynika z tego, że przejazd tramwajowego zestawu kołowego po łuku toru zbudowanego z szyn kolejowych bez poszerzenia prześwitu toru jest możliwy.

\subsubsection{Przejazd tramwajowego zestawu kolowego po tuku toru zbudowanego z szyn tramwajo- wych}

W oparciu o pkt. 3.1 .2 i 3.2.4 przejazd tramwajowego zestawu kołowego po łuku toru zbudowanego z szyn tramwajowych jest w pełni możliwy.

3.3. Omówienie i wnioski wynikające ze współpracy po lukach torów

\subsubsection{Szerokość kota dla tramkolu}

Należy wyznaczyć $f_{\text {uniw }}$, czyli szerokość koła dla pojazdu tramwajowo-kolejowego w oparciu o istniejące wymiary kół tramwajowych i kolejowych. Sytuacje przedstawiono na rys. 8 .

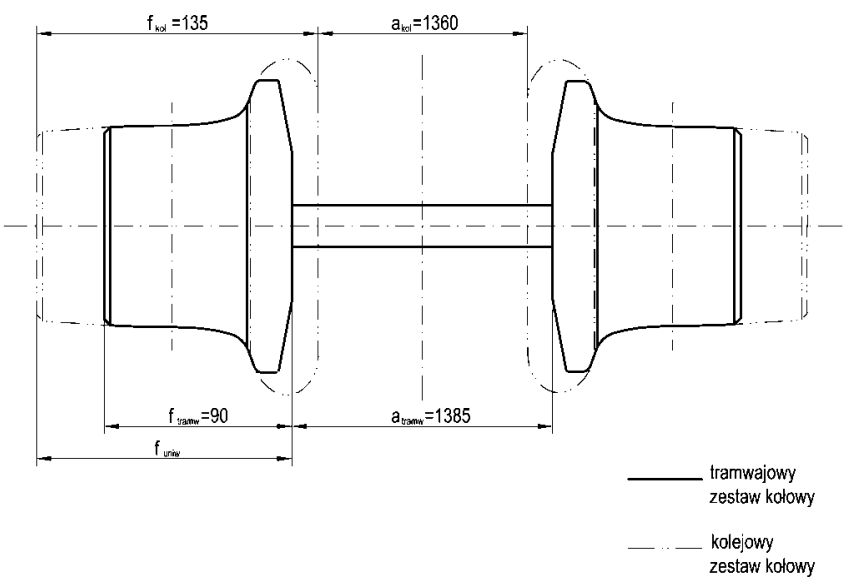

Rys. 8. Szerokość koła dla pojazdu tramwajowokolejowego

Zachodzi zależność

$$
a_{\text {kol }}+2 f_{\text {kol }}=a_{\text {tramw }}+2 f_{\text {uniw }}
$$

Stąd nominalny wymiar $f_{\text {uniw }}$ wynosi:

$f_{\text {uniw }}=\frac{a_{\text {kol }}-a_{\text {tramw }}+2 f_{\text {kol }}}{2}=\frac{1360-1385+2 \cdot 135}{2}=122,5 \mathrm{~mm}$

Wymiar ten należy stolerować na $122,5^{ \pm 1} \mathrm{~mm}$. Tolerancje eksploatacyjne tego wymiaru będą takie, jak dla koła kolejowego, czyli $f_{\text {uniw }}=122,5_{-2}^{+5} \mathrm{~mm}$.

\subsubsection{Wystawanie kola poza zewnętrznq szyne}

Dla wyznaczonej szerokości koła $f_{\text {uniw }}$ przedstawiono na rys.9 tramwajowy zestaw kołowy oraz zestaw uniwersalny dla tramkolu, stojące na torze zbudowanym $\mathrm{z}$ szyn tramwajowych zatopionych w jezdni (tolerancje na rysunku są tolerancjami eksploatacyjnymi) $\mathrm{w}$ położeniu skrajnie przesuniętym do zewnętrznej szyny łuku toru.

Zachodzą zależności:

$$
\begin{aligned}
& \Delta y_{\text {tramw }}+F+b_{\text {tramw }}=f_{\text {tramw }} \\
& \Delta y_{\text {uniw }}+F+b_{\text {uniw }}=f_{\text {uniw }}
\end{aligned}
$$

Stąd

$$
\begin{aligned}
& \Delta y_{\text {tramw }}=f_{\text {tramw }}-b_{\text {tramw }}-F \\
& \Delta y_{\text {uniw }}=f_{\text {uniw }}-b_{\text {uniw }}-F
\end{aligned}
$$

$\Delta y_{\text {tramw }}$ będzie największe, gdy $\mathrm{f}_{\text {tramw }}$ będzie największe, a $b_{\text {tramw }}$ i $\mathrm{F}$ będzie najmniejsze.

Zatem wg (6):

$$
\Delta y_{\text {tramw }}=91-13-47=31 \mathrm{~mm}
$$




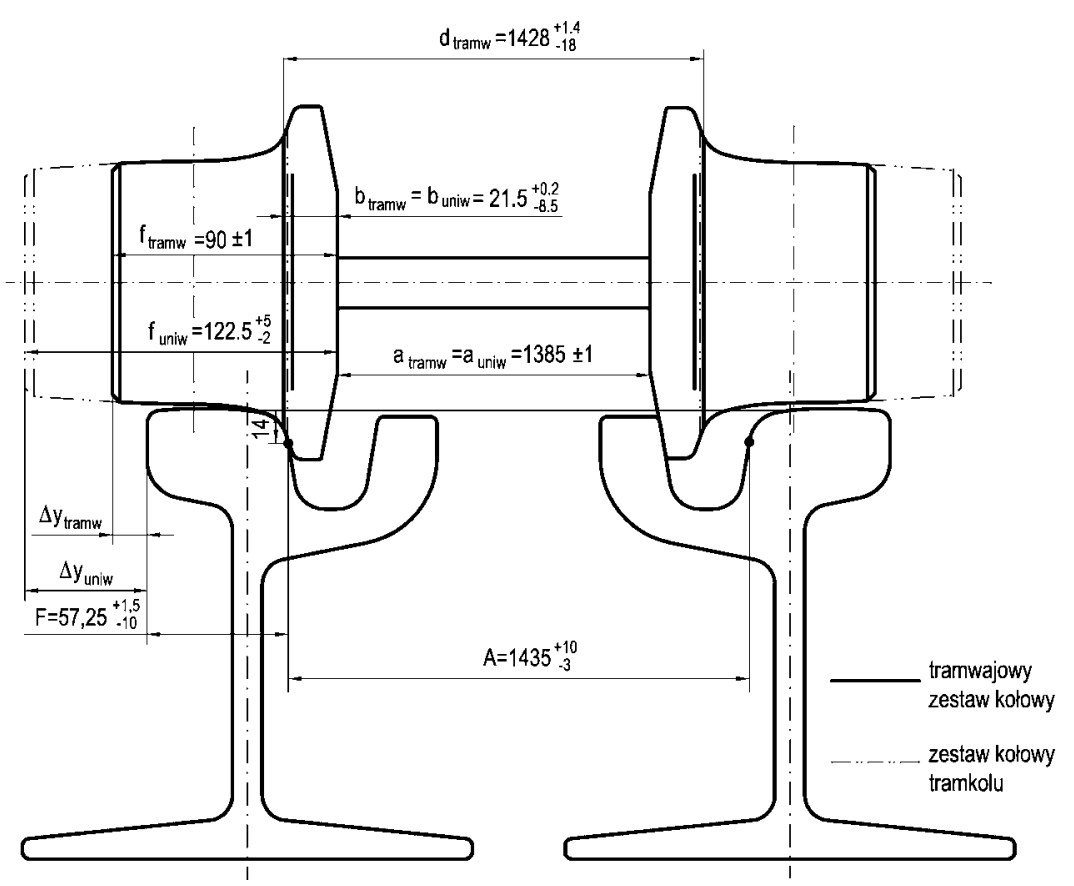

Rys.9. Wystawanie koła poza zewnętrzną szynę łuku toru przy skrajnym przesunięciu zestawu kołowego

Analogicznie wg (7):

$$
\Delta y_{\text {uniw }}=127,5-13-47=67,5 \mathrm{~mm}
$$

Koło uniwersalnego zestawu kołowego wystawałoby o 67,5 mm poza szynę na łuku toru, podczas gdy koło tramwajowe wystaje tylko o $31 \mathrm{~mm}$. Na torze prostym koło uniwersalnego zestawu kołowego, ustawionego symetrycznie $\mathrm{w}$ środkowym położeniu $\mathrm{w}$ ramach luzów w torze, wystawałoby poza szynę w sposób ciągły o wielkość:

$$
\Delta y_{\text {pr tramw }}=\frac{a_{\text {tramw }}+2 f_{\text {tramw }}-(A+2 F)}{2}
$$

Przy tym długość A+2F jest dla danego toru wielkością stałą, zależną tylko od odchyłek wykonawczych, a niezależną od zużycia szyn.

Zatem $\Delta y_{\text {prtramw }}$ będzie największe, gdy $\mathrm{a}_{\text {tramw }}$ oraz $\mathrm{f}_{\text {tramw }}$ będą największe, a długość $\mathrm{A}+2 \mathrm{~F}$ będzie najmniejsza.

$\mathrm{Z}$ równania (8) otrzymuje się (decydują tolerancje wykonawcze):

$$
\Delta y_{\text {prtramw }}=\frac{1386+2 \cdot 91-1545,5}{2}=11,2 \mathrm{~mm}
$$

Wokół tej wartości wielkość $\Delta y$ będzie oscylować podczas ruchów wężykowania zestawu kołowego, ale to będą przemieszczenia chwilowe, z których każde trwa najwyżej ułamek sekundy i można je pominać. Analogicznie będzie dla koła uniwersalnego:

$$
\Delta y_{\text {pruniw }}=\frac{1386+2 \cdot 127,5-1545,5}{2}=47,7 \mathrm{~mm}
$$

Uniwersalne koło wystawałoby poza szynę o 47,7 mm, podczas gdy koło tramwajowe wystaje tylko o 11,2 $\mathrm{mm}$.

\subsubsection{Podnoszenie kota ponad po- ziom jezdni}

Gdy tor jest zatopiony w jezdni ulicy, to obok szyn znajduje się nawierzchnia jezdni, przeważnie asfaltowa, czasem wykonana $\mathrm{z}$ kostek kamiennych, a często jest to płyta betonowa. $\mathrm{Z}$ reguły między główką szyny a krawędzią asfaltowej czy betonowej jezdni występuje szczelina o szerokości około $20 \mathrm{~mm}$.

Nierzadkie są miejsca we wszystkich miastach polskich, w których tor zapadł się aż o $30 \mathrm{~mm} w$ stosunku do poziomu jezdni. Gdy koło tramwajowe wystaje poza główkę szyny o $11,2 \mathrm{~mm}$, to nic się wtedy nie dzieje, gdyby jednak koło uniwersalne musiało wystawać poza główkę szyny o 47,7 mm, to w miejscu, gdzie tor się zapadł, wytworzy się sytuacja przedstawiona na rys. 10.

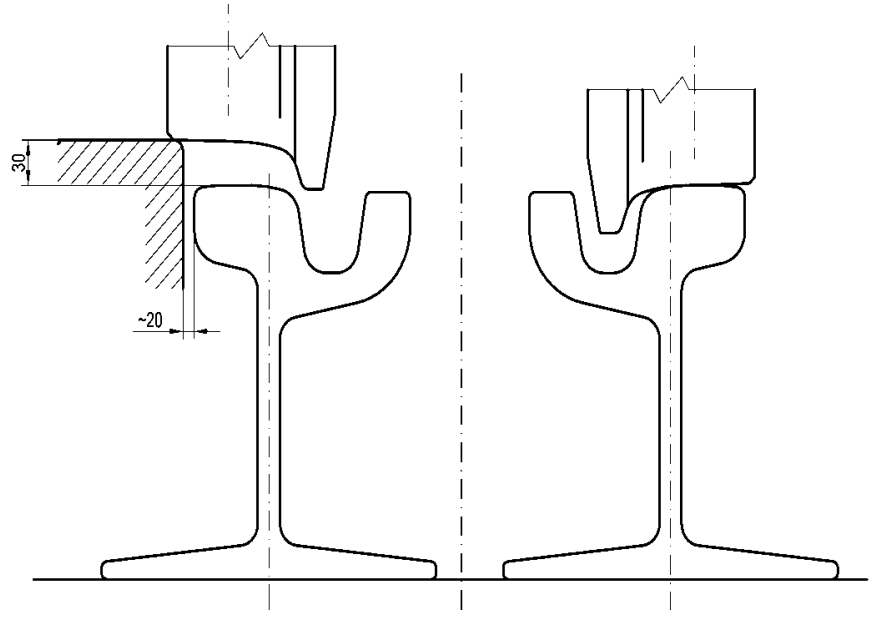

Rys.10. Przejazd uniwersalnego zestawu kołowego przez zapadnięty tor tramwajowy

Jak widać z rysunku 10 , koło podniesie się na płytę betonowa, a to już jest wykolejenie.

Zatem przedsiębiorstwo tramwajowe $\mathrm{w}$ przypadku użytkowania uniwersalnych zestawów kołowych w tramkolach musiałoby bardzo skrupulatnie pilnować, aby wszelkie zapadnięcia toru były systematycznie natychmiast naprawione na całej długości torów tramwajowych, po których poruszałyby się tramkole. Obecnie takie naprawy są dokonywane tylko na łukach torów, gdyż tam koła tramwajowe mogą wystawać o $32 \mathrm{~mm}$ poza główkę szyny, a więc mogłyby podnieść się na asfalt i wykolejać. 


\subsubsection{Wnioski}

Dla pojazdu, który byłby w stanie poruszać się po torach tramwajowych i jednocześnie po torach kolejowych należałoby:

a) zastosować zestawy kołowe o szerokości wieńca koła równej $f_{\text {uniw }}=122,5^{ \pm 1} \mathrm{~mm}$.

b) dokonać przeróbki wszystkich łuków na linii kolejowej, po której miałyby jeździć tramkole, na łuki pozbawione poszerzenia prześwitu toru. Tak przerobiony łuk zachowałby zdolność do prowadzenia pojazdów kolejowych, gdyż poszerzenie toru na łukach nie jest konieczne.

Wobec braku poszerzenia toru wystarczyłaby szerokość koła taka, jaką stosuje się w tramwajach, czyli $f_{\text {tramw }}=90^{ \pm 1} \mathrm{~mm}$. Oczywiście, koszt przeróbki łuków byłby znaczny, ale jest to koszt jednorazowy.

\section{Jazda po zwrotnicach}

\subsection{Budowa zwrotnic}

\subsubsection{Budowa zwrotnicy kolejowej}

Schemat zwrotnicy kolejowej pokazano na rys.11.

\subsubsection{Budowa zwrotnicy tramwajowej}

$\mathrm{W}$ tramwajnictwie istnieje inna zasada przejeżdżania przez serca zwrotnic niż na kolejach. Serce zwrotnicy tramwajowej jest wykonane ze specjalnie ukształtowanej bryły metalowej, w której są wyżłobione dwie przecinające się z sobą płytkie koleiny o głębokości $10_{-1}^{+9} \mathrm{~mm}$ (tolerancje eksploatacyjne) i o szerokości równej szerokości rowka szyny tramwajowej.

\subsection{Jazda po zwrotnicy kolejowej \\ 4.2.1. Serce zwrotnicy kolejowej}

Wymiary serca zwrotnicy kolejowej pokazano na rys. 12 .

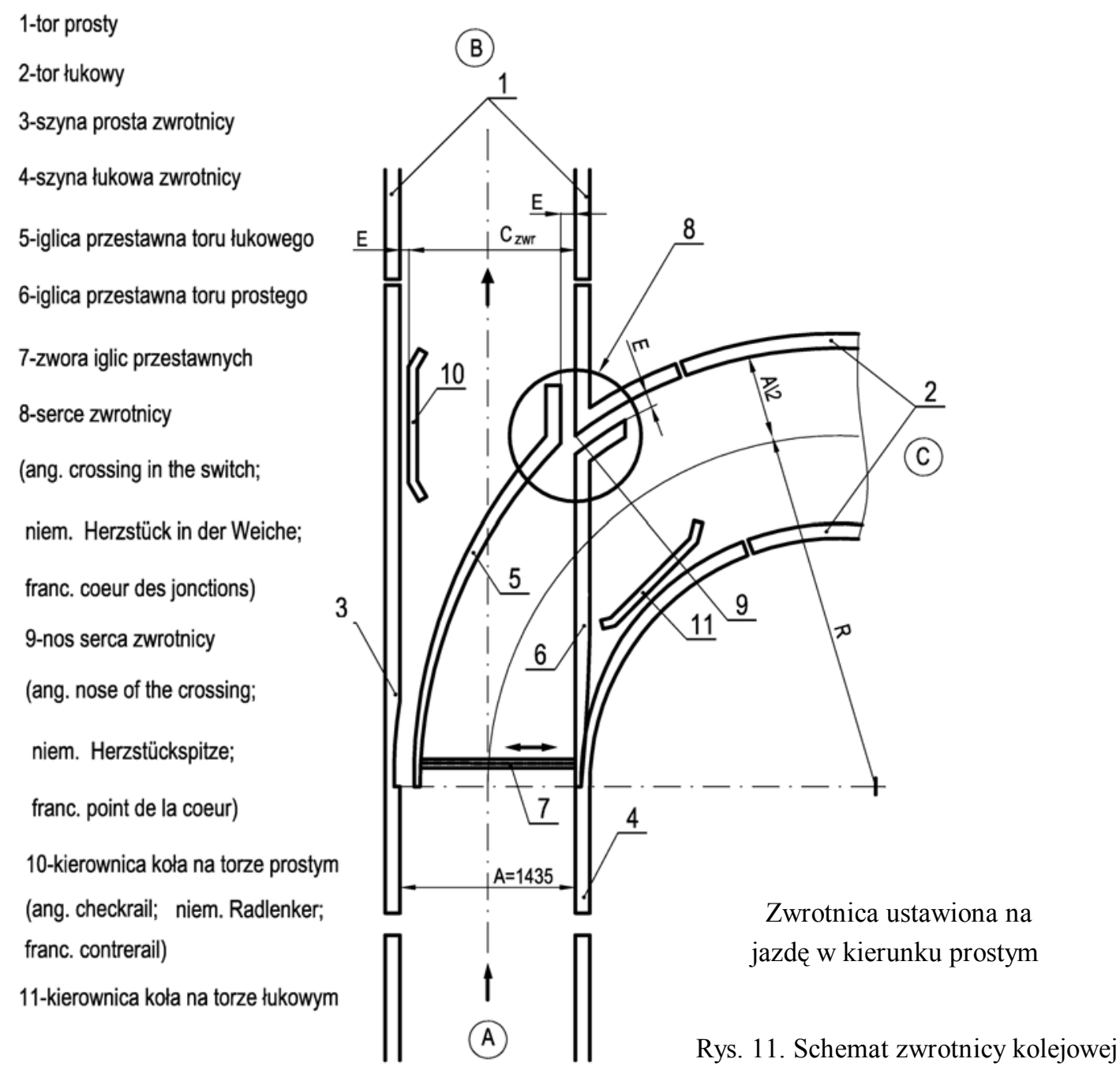



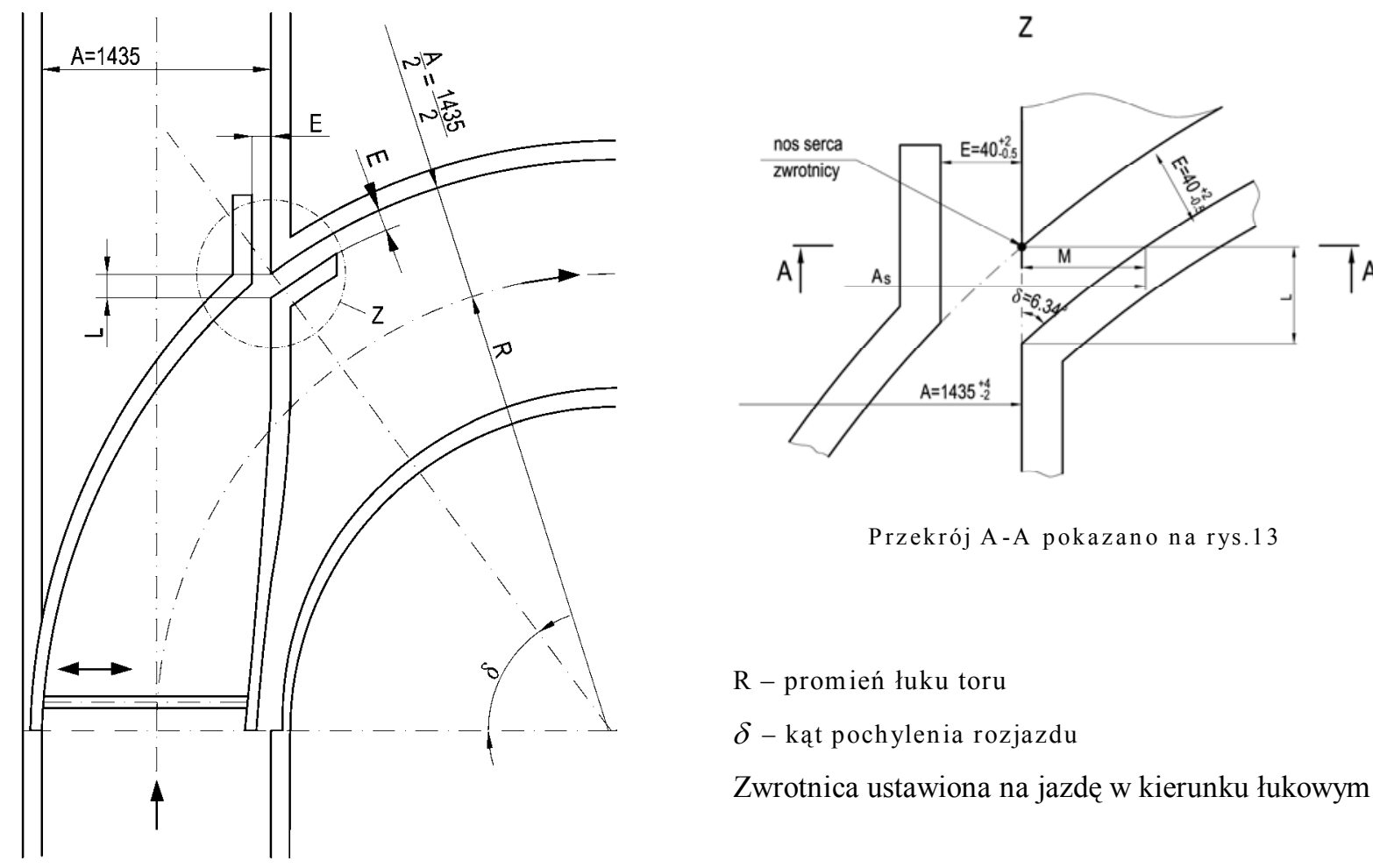

Rys. 12. Wymiary serca zwrotnicy kolejowej

Zachodzi zależność:

$$
\left(R+\frac{A}{2}\right) \cdot(1-\cos \delta)=A
$$

Podstawiając $\quad(1-\cos \delta)=2 \sin ^{2} \frac{\delta}{2}$,

$$
\text { to } \quad\left(R+\frac{A}{2}\right) \cdot 2 \sin ^{2} \frac{\delta}{2}=A
$$

Stąd otrzymuje się:

$$
\sin \frac{\delta}{2}=\sqrt{\frac{A}{2 R+A}}
$$

Zakłada się, że tramkole będą kursowały po torach kolejowych, których łuki $\mathrm{R} \geq 150 \mathrm{~m}$.

Ze wzoru (9) otrzymuje się:

$\sin \frac{\delta}{2}=\sqrt{\frac{A}{2 R+A}}=\sqrt{\frac{1435}{2 \cdot 150000+1435}}=0,068996825$

i stąd:

$$
\frac{\delta}{2}=3,956^{0} \quad \delta=7,912^{0}
$$

oraz

$$
\operatorname{tg} \delta=0,138988119=1: 7,194859567
$$

Gdy R rośnie, to $\frac{\delta}{2}$ maleje, a zatem również $\operatorname{tg} \delta$ maleje.
Ale $\operatorname{tg} \delta$ nie może być zbyt mały, gdyż wtedy nos serca zwrotnicy byłby bardzo cienki i łatwo mógłby ulec uszkodzeniu. Związek UIC zalecił w pkt. J.7 karty UIC 510-2 [6], że najmniejszy dopuszczalny kąt pochylenia rozjazdu $\delta$ wynosi $\operatorname{tg} \delta=\frac{1}{9}=0,111111$. Należy wyznaczyć promień R, dla którego wystapi powyższa wartość.

Z wzoru (9):

$R=\frac{1}{2}\left(\frac{A}{\sin ^{2} \frac{\delta}{2}}-A\right)=\frac{1}{2}\left(\frac{1435}{0,003059553}-1435\right)=233793,9 \mathrm{~mm}$

Wystarczy rozpatrzyć wartość kąta $\delta=6,34^{\circ}$, dla którego $\operatorname{tg} \delta=1: 9$.

Szerokość koleiny wraz $\mathrm{z}$ tolerancjami eksploatacyjnymi według pkt. J.7 karty UIC 510-2 [6] wynosi $E=40_{-0,5}^{+2} \mathrm{~mm}$.

Wg rys. 12 zachodzą zależności wymiarowe:

$L=\frac{E}{\sin \delta}=\frac{40_{-0,5}^{+2}}{\sin 6,34^{0}}=\frac{40_{-0,5}^{+2}}{0,1104330} \approx 362_{-4}^{+18} \mathrm{~mm}$ $M=\frac{E}{\cos \delta}=\frac{40_{-0,5}^{+2}}{\cos 6,34^{0}}=\frac{40_{-0,5}^{+2}}{0,9938836} \approx 40_{-0,25}^{+2,25} \mathrm{~mm}$

Szerokość prześwitu toru prostego w przekroju A-A wraz z tolerancjami eksploatacyjnymi zwrotnicy wynosi $A=1435_{-2}^{+4} \mathrm{~mm}$ 
Szerokość ta powiększona o wymiar M skośnej koleiny w przekroju A-A wynosi:

$$
A_{s}=A+M=1435_{-2}^{+4}+40_{-0,25}^{+2,25}=1475_{-2,25}^{+6,25} \approx 1475_{-2}^{+6} \mathrm{~mm}
$$

Największa dopuszczalna wartość tego wymiaru wyniesie $A_{s \text { max }}=1481 \mathrm{~mm}$.

\subsubsection{Potrzebna szerokość kota kolejowego}

Zestaw kołowy może przejeżdżać nad sercem zwrotnicy od wjazdu (A) do wyjazdu (B) (rys. 11), między innymi $\mathrm{w}$ ten sposób (przypadek skrajny), że obrzeże jego lewego koła będzie biegło tuż przy szynie 3, a obrzeże prawego koła będzie oddalone od iglicy 6 o największą możliwą odległość.

Wytworzy się sytuacja pokazana na rys. 13 .

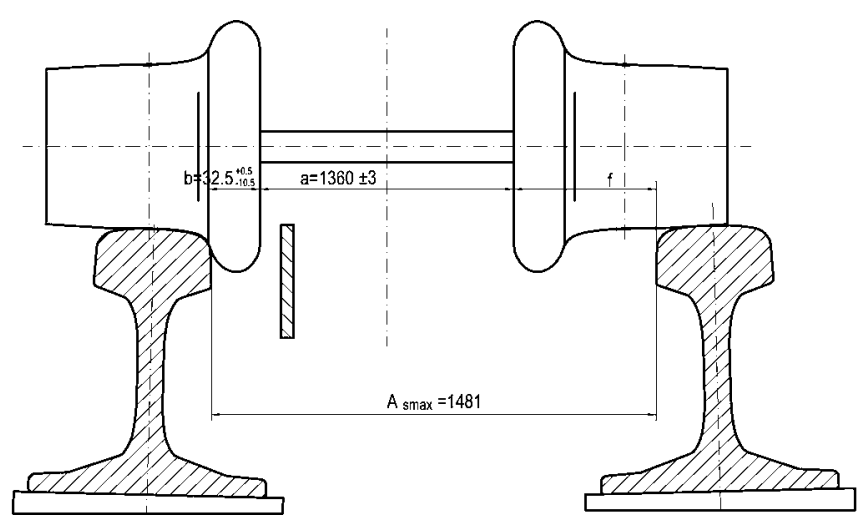

Rys. 13 - Skrajne lewe ustawienie kolejowego zestawu kołowego w zwrotnicy (przekrój A-A z rys.12)

Zachodzi zależność

$$
\underset{\text { czyli }}{f>A_{s \max }-\left(b_{\text {min }}+a_{\text {min }}\right)}
$$

Akurat tyle wynosi załamanie krawędzi nowego koła. Wobec tego ta wartość pokrycia jest stanowczo za mała. Potrzebna jest większa szerokość koła tramwajowego.

\subsubsection{Jazda kolejowego zestawu kolowego po zwrotnicy kolejowej $w$ kierunku prostym $w$ skrajnie prawym polożeniu}

Jazda od wejścia (A) do wyjścia (B) (rys.11), jest bardziej niekorzystna niż jazda $\mathrm{w}$ kierunku odwrotnym ze względu na to, że koło prawe toczące się po szynie 4 i dalej po iglicy toru prostego 6 napotyka $\mathrm{w}$ sercu 8 zwrotnicy wzajemne przecięcie się dwu kolein, na którym koło to traci swe prowadzenie boczne $\mathrm{z}$ prawej strony i może próbować skręcić $\mathrm{w}$ prawo $\mathrm{W}$ kierunku łukowym do wyjścia (C), w efekcie czego trafiłoby ono na nos 9 i mogłoby się podnieść i wykoleić. Jednak utrata prowadzenia bocznego tego koła jest skompensowana wtedy przez kierownice 10, jaka w tym czasie prowadzi lewe koło, które dzięki temu musi toczyć się po szynie prostej 3 , a wraz z nim cały zestaw kołowy porusza się po torze prostym od wejścia (A) do wyjścia (B).

Szczelina między kierownicą 10 a szyną 3 ma szerokość $E=40_{-0,5}^{+2} \mathrm{~mm}$, a tak zwana szerokość prowadząca zwrotnicy (ang.,,guiding width”; niem. „Leitweite"; franc.,„cote de protection de pointe”) wynosi $C_{Z W R}=1395_{-2}^{+3} \mathrm{~mm}$ (tolerancje eksploatacyjne).

W sercu zwrotnicy obie koleiny są ,pustą przestrzenią" (szczegół Z na rys.12).

Ustawienie kolejowego zestawu kołowego tuż przed nosem serca zwrotnicy, gdy prowadzi go kierownica lewego koła, pokazano na rys. 14 .

$f>1481-(22+1357)=102 \mathrm{~mm}$

Koło kolejowe ma szerokość $f_{\text {kol }}=135_{-2}^{+5} \mathrm{~mm}$, a więc spełnia warunek, że $f_{\text {kol }}>102 \mathrm{~mm}$.

\subsubsection{Potrzebna szerokość koła tramwajowego}

Rozważania te będą identyczne jak w punkcie $4.2 .2 \mathrm{z}$ tą różnica, że dla tramwajowego zestawu kołowego: $b=21,5_{-8,5}^{+0,2} \mathrm{~mm}$ i $a=1385^{ \pm 1} \mathrm{~mm}$.

W tym przypadku z nierówności (10) otrzyma się:

$$
f>1481-(13+1384)=84 \mathrm{~mm}
$$

Tramwajowe koło ma szerokość $f_{\text {tramw }}=90^{ \pm 1} \mathrm{~mm}$.

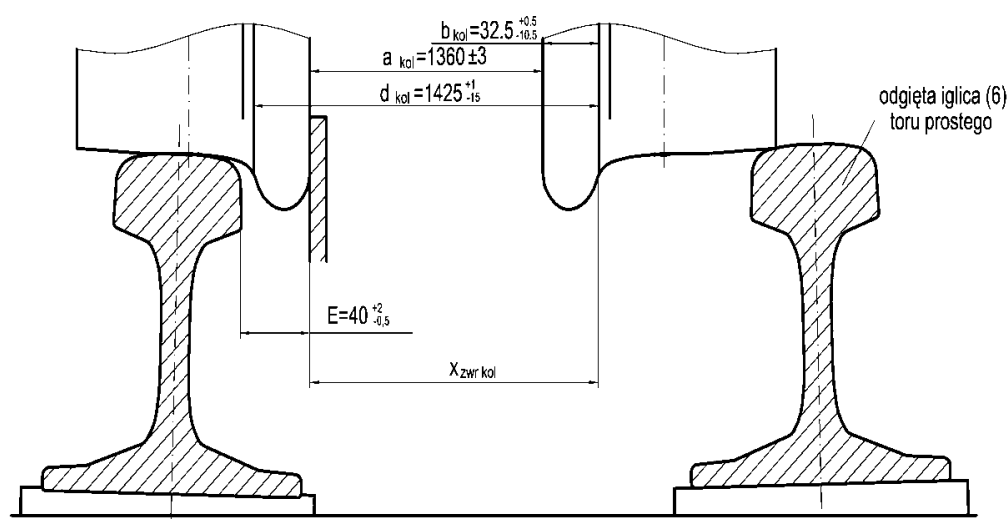

Zatem pokrywa ono prawą szynę tylko szerokością równą w skrajnym przypadku

$$
\Delta f=89-84=5
$$




\section{Zachodzi zależność}

$$
X_{z w r k o l}=a_{k o l}+b_{k o l}
$$

$\mathrm{X}_{\mathrm{zwr}}$ kol byłoby największe, gdyby $\mathrm{a}_{\mathrm{kol}}$ oraz $\mathrm{b}_{\mathrm{kol}}$ były największe dopuszczalne.

Wtedy

$$
X_{z w r}=1363+33=1396 \mathrm{~mm}
$$

Ale dla nowego zestawu kołowego z tolerancji wykonawczych $d_{k o l}=1425^{ \pm 1} \mathrm{~mm}$ wynika, że górna odchyłka sumy wymiarów $a_{\text {kol }}+2 b_{\text {kol }}$ nie może być większa niż $+1 \mathrm{~mm}$. Na nowym zestawie kołowym wymiar $a_{\text {kol }}$ wynosi $1360_{-0}^{+2} \mathrm{~mm}$, czyli największy możliwy wymiar $a_{\text {kol }} \mathrm{w}$ stanie nowym wynosi 1362 $\mathrm{mm}$.

Jedno obrzeże może mieć największą dopuszczalną grubość $33 \mathrm{~mm}$.

Wtedy obrzeże drugiego koła może mieć najwyżej grubość $\mathrm{x}_{\mathrm{b}}$. Zachodzi zależność $1426=1362+33+\mathrm{x}_{\mathrm{b}} \mathrm{i}$ $\mathrm{x}_{\mathrm{b}}=31 \mathrm{~mm}$.

Jest mało prawdopodobne, aby nowy zestaw kołowy został wykonany z taką różnicą grubości obu obrzeży kół. Można zatem przyjaćc, że górna odchyłka łącznego wymiaru $\mathrm{a}_{\mathrm{kol}}+\mathrm{b}_{\mathrm{kol}}$, nie przekroczy $2 \mathrm{~mm}$.

Zatem największa szerokość prowadzona zestawu kołowego w zwrotnicy kolejowej według równania (11) wynosi:

$$
X_{z w r}=(1360+32,5)^{+2}=1392,5^{+2} \mathrm{~mm}
$$

Największa wartość tej szerokości prowadzonej zestawu kołowego w zwrotnicy wynosi

$$
\left(X_{z w r}\right)_{\max }=1394,5 \mathrm{~mm} \text {. }
$$

Z drugiej strony szerokość prowadząca zwrotnicy wynosi: $C_{z w r}=1395_{-2}^{+3} \mathrm{~mm}$.

Najmniejsza szerokość prowadząca zwrotnicy wynosi $\left(C_{z w r}\right)_{\min }=1393 \mathrm{~mm}$.

W skrajnym przypadku szerokość prowadząca zwrotnicy jest mniejsza niż szerokość prowadzona zestawu kołowego.

Zatem w najbardziej niekorzystnym przypadku obrzeże koła nachodzi na nos serca zwrotnicy o wielkość y.

$y=\left(X_{z w r}\right)_{\max }-\left(C_{z w r}\right)_{\min }=1394,5-1393=1,5 \mathrm{~mm}$

Wzajemne ustawienie obrzeża koła i nosa zwrotnicy w najbardziej niekorzystnym przypadku pokazano na rys. 15 i 16.

\section{Zachodzi zależność:}

$m=c+y \cdot \operatorname{tg} 70^{\circ}=10+1,5 \cdot 2,747=14,12 \approx 14 \mathrm{~mm}$

$D_{\text {nat }}=D_{k o l}+2 \cdot m=D_{k o l}+2 \cdot 14=D_{k o l}+28$

Obniżenie czoła nosa wynosi $\mathrm{y}_{\mathrm{n}}=8 \mathrm{~mm}$ według karty UIC 510-2 [6]. Zatem kąt natarcia koła na nos wyniesie:

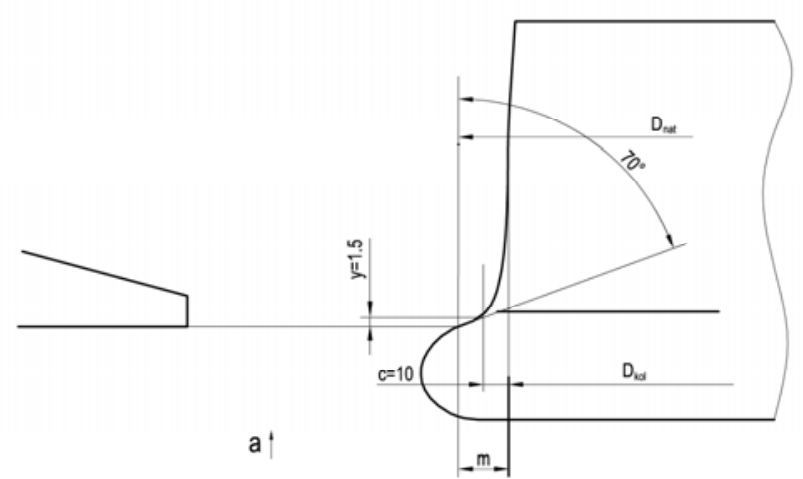

Rys.15 Najbardziej niekorzystne wzajemne ustawienie koła kolejowego względem nosa serca zwrotnicy kolejowej

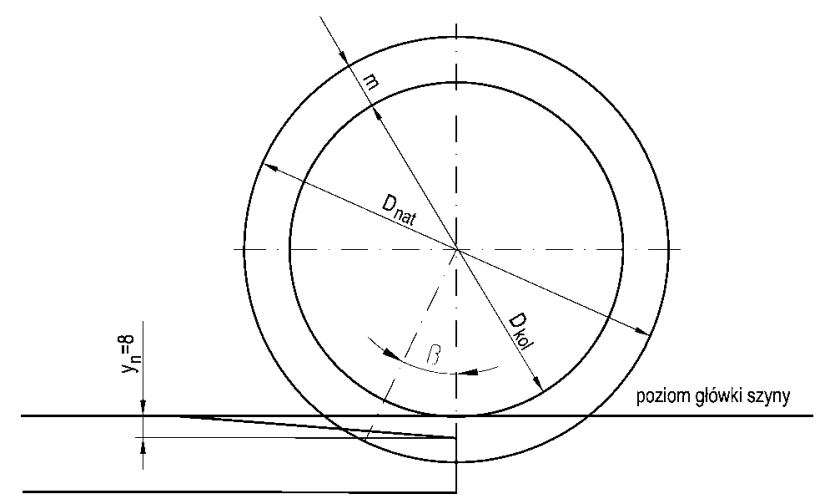

Rys.16 Widok „a” z rys.15 w chwili, gdy środek koła znajduje się nad nosem serca zwrotnicy

$$
\cos \beta=\frac{\frac{D_{k o l}}{2}+y_{n}}{\frac{D_{k o l}+2 m}{2}}=\frac{D_{k o l}+2 y_{n}}{D_{k o l}+2 m}
$$

Rozpatrywany niekorzystny przypadek ma miejsce, gdy koło jest nowe. Średnica nowego kolejowego koła wagonowego wynosi $D_{\text {kol }}=920 \mathrm{~mm}$.

Zatem

$$
\cos \beta=\frac{920+2 \cdot 8}{920+2 \cdot 14}=\frac{936}{948}=0,987341772
$$

Stąd

$$
\beta=9,1260589 \approx 9^{0}
$$

Koło wchodzi $\mathrm{w}$ styk $\mathrm{z}$ nosem niemal stycznie do niego. $\mathrm{Z}$ łatwością wślizgnie się ono po powierzchni bocznej nosa, przy czym zestaw kołowy zostanie łagodnie (ale skutecznie) odepchnięty na powrót w bok o kolidującą wartość $\mathrm{y}_{\mathrm{n}}=1,5 \mathrm{~mm} \mathrm{w}$ kierunku do środka toru.

Takie zachowanie się zestawu kołowego przewidziano w karcie UIC 510-2 [6] (droga odepchnięcia powrotnego, niem. „Rückdrangweg”).

Zatem dzięki kierownicy 10 zestaw kołowy nie uniesie się na nos 9 w sercu 8 zwrotnicy, lecz bok roboczy obrzeża koła toczącego się uprzednio po iglicy 6 wślizgnie się po powierzchni roboczego boku nosa 9, odpychając zestaw kołowy w bok o droge 
odepchnięcia $\mathrm{y}_{\mathrm{n}}$ i tym sposobem kolejowy zestaw kołowy przejedzie bezpiecznie przez serce zwrotnicy kolejowej 8.

\subsubsection{Jazda kolejowego zestawu kolowego po zwrotnicy kolejowej w kierunku tukowym}

Toczenie się zestawu kołowego od wejścia (A) do wyjścia (C) na rys. 11 początkowo odbywa się w taki sposób, że lewe koło jest prowadzone przez iglicę toru łukowego 5 aż do chwili, gdy napotyka ono szczelinę $\mathrm{w}$ sercu zwrotnicy i wtedy koło utraci prowadzenie boczne.

Jednak utrata prowadzenia bocznego lewego koła jest skompensowana przez kierownice 11 , jaka teraz prowadzi prawe koło, które dzięki temu musi toczyć się po szynie łukowej 4, a wraz z nim cały zestaw kołowy skręca tocząc się od wejścia (A) do wyjścia (C). Rachunek wymiarowy jest identyczny, jak dla jazdy w kierunku prostym i wyniki są takie same.

\subsubsection{Jazda tramwajowego zestawu kolowego po zwrotnicy kolejowej $w$ kierunku prostym $w$ skrajnie prawym potożeniu}

Analiza będzie analogiczna jak w punkcie $4.2 .4 \mathrm{z}$ ta różnica, że zamiast wymiaru $\mathrm{a}_{\mathrm{kol}}=1360^{ \pm 3} \mathrm{~mm}$ wystapi wymiar $\mathrm{a}_{\text {tramw }}=1385^{ \pm 1,4} \mathrm{~mm}$, a zamiast wymiaru $b_{k o l}=32,5_{-10,5}^{+0,5} \mathrm{~mm}$ wystapi wymiar $b_{\text {tramw }}=21,5_{-8,5}^{+0,2}$ mm (rys. 14).

Równanie (11) przyjmuje postać:

$$
\begin{aligned}
& X_{\text {zwr tramw }}=\left(a_{\text {tramw }}+b_{\text {tramw }}\right)^{ \pm 1,6}=(1385+21,5)^{ \pm 1,6}= \\
& =1406,5^{ \pm 1,6} \mathrm{~mm}
\end{aligned}
$$

Szerokość prowadząca zwrotnicy (rys. 11) wynosi $C_{z w r}=1395_{-2}^{+3} \mathrm{~mm}$

Nachodzenie obrzeża koła na nos serca zwrotnicy może wynosić:

$$
y_{\text {tramw }}=1406,5^{ \pm 1,6}-1395_{-2}^{+3}=11,5_{-4,6}^{+3,6} \mathrm{~mm}
$$

czyli w najbardziej niekorzystnym przypadku 15,1 $\mathrm{mm}$.

Wzajemne ustawienie obrzeża koła i nosa zwrotnicy $\mathrm{w}$ najbardziej niekorzystnym przypadku przedstawiono na rys. 17 (podczas jazdy po łuku od wjazdu (A) do

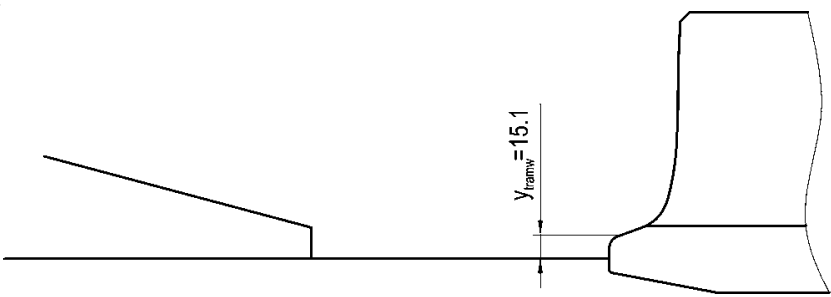

Rys.17 Najbardziej niekorzystne wzajemne ustawienie koła tramwajowego względem nosa serca zwrotnicy kolejowej
Możliwe ustawienie pokazane na rys. 17 spowoduje natychmiastowe wykolejenie tramwajowego zestawu kołowego, gdyż szerokość prowadzona tramwajowego zestawu kołowego w zwrotnicy równa $\mathrm{X}_{\mathrm{zwr} \text { tramw }}$ $=1406,5^{ \pm 1,6} \mathrm{~mm}$ jest dużo większa od szerokości prowadzącej zwrotnicy równej $C_{z w r}=1395_{-2}^{+3} \mathrm{~mm}$, skutkiem czego kierownica zwrotnicy kolejowej przestaje spełniać swoją funkcję, tzn. nie jest zdolna do prowadzenia tramwajowego zestawu kołowego w zwrotnicy kolejowej.

\subsection{Jazda po zwrotnicy tramwajowej \\ 4.3.1. Jazda kolejowego zestawu kolowego po zwrotnicy tramwajowej}

Jazda taka jest niemożliwa, gdyż obrzeża kół kolejowych w żaden sposób nie pasują do rowków szyn tramwajowych, a poza tym obrzeże koła kolejowego jest zaokraglone hukiem o promieniu $12 \mathrm{~mm}$ i przez to okrag wierzchołkowy koła nie nadaje się w ogóle do toczenia się po jakiejkolwiek powierzchni.

\subsubsection{Jazda tramwajowego zestawu kolowego po zwrotnicy tramwajowej}

Jazda taka może odbywać się bezproblemowo.

Koło tramwajowe przejeżdża przez serce zwrotnicy tramwajowej $\mathrm{w}$ ten sposób, że toczy się ono swoim kregiem wierzchołkowym obrzeża po dnie jednej $\mathrm{z}$ kolein, zależnie od nastawienia zwrotnicy.

Koło to jest prowadzone bocznie trochę przez tę koleinę, a głównie przez drugie koło tego samego zestawu kołowego, które toczy się wtedy w rowku zwykłej szyny tramwajowej i jest prowadzone przez prowadnicę tej szyny.

Zasada ta funkcjonuje zadawalająco. Ponieważ uniwersalny zestaw kołowy posiada takie samo obrzeże jak tramwajowy, to będzie on przejeżdżał przez serca zwrotnic tramwajowych tak samo nienagannie jak tramwajowy zestaw kołowy.

\subsection{Omówienie $\mathrm{i}$ wnioski wynikające $\mathrm{z}$ jazdy po zwrotnicy}

\subsubsection{Szerokość kola dla tramkolu}

Aby uniwersalnemu zestawowi kołowemu (dla tramkolu) umożliwić jazdę po zwrotnicach kolejowych, należałoby po wewnętrznej stronie koła tramwajowego dodać warstwę materiału o odpowiedniej grubości, aby odległość pomiędzy czołami tych dodatkowych warstw materiału na obu kołach wynosiła $a_{\text {kol }}=$ $1360^{ \pm 1} \mathrm{~mm}$.

Jednak $\mathrm{z}$ uwagi na konieczność współpracy uniwersalnego zestawu kołowego $\mathrm{z}$ torem zbudowanym $\mathrm{z}$ szyn tramwajowych, ta dodatkowa warstwa materiału nie może pojawić się niżej niż na pewnej wysokości „," ponad główką szyny, takiej, aby w żadnym stanie zużycia koła ta dodatkowa warstwa materiału nie zeszła poniżej poziomu główki szyn. 
Ta wysokość ,i” musi kompensować następujące elementy:

- zużycie pionowe główki szyny

- zużycie radialne koła między dwoma kolejnymi reprofilowaniami; można założyć, że koło będzie reprofilowane każdorazowo po zużyciu radialnym (pionowym) równym $\delta_{k}=8 \mathrm{~mm}$

- na szynie $180 \mathrm{P}$ według normy $\mathrm{PN}-92 / \mathrm{H}-$ 93440 [9] górna krawędź prowadnicy szyny w stanie nowym leży o $3 \mathrm{~mm}$ wyżej niż poziom główki szyny; wielkość ta również musi zostać uwzględniona

- tolerancję wykonawczą dodatnią wymiaru ,i”, równą $1 \mathrm{~mm}$

- minimalny luz pomiędzy najbardziej zużytym kołem, a prowadnicą szyny o najbardziej zużytej bieżni, równy $1 \mathrm{~mm}$.

Wielkość ,i” powinna być odnawiana $\mathrm{z}$ tolerancją wykonawczą przy każdym reprofilowaniu koła.

Według [12] promień zaokrąglenia wewnętrznego boku obrzeża typowego koła kolejowego wynosi 20,5 mm. Ponieważ podczas wchodzenia dodatkowej warstwy materiału koła uniwersalnego zestawu kołowego w kierownicę zwrotnicy sytuacja jest identyczna jak w przypadku wchodzenia obrzeża typowego koła kolejowego w tę kierownicę, to promień zaokraglenia tej dodatkowej warstwy materiału musi być taki sam, jak promień zaokraglenia wewnętrznego boku obrzeża koła kolejowego, a kąt nachylenia wprowadzenia dodatkowej warstwy materiału do poziomu według [12] powinien wynosić co najmniej $40^{\circ}$.

\subsubsection{Wysokość kierownicy szyny}

Aby dodatkowa warstwa materiału spełniała swoje zadanie, musi ona swą płaską powierzchnią kontaktować się z kierownicą szyny na wysokości co najmniej $10 \mathrm{~mm}$.

Zatem kierownica szyny musiałaby mieć wysokość co najmniej równą $H$ ponad główkę szyny, a więc musiałaby być wyższa od istniejących kierownic.

Takich kierownic w zwrotnicach dotychczas w Polsce nie ma . Trzeba by wykonać specjalne kierownice o wysokości H. Na trasach, po których miałyby kursować tramkole trzeba by wszystkie kierownice zwrotnic wymienić na kierownice o wysokości H z tolerancją eksploatacyjną $\mathrm{H}^{+10} \mathrm{~mm}$ (zgodnie $\mathrm{z}$ kartą UIC 510-2 [6] zużycie pionowe główki szyny w zwrotnicy może wynieść $10 \mathrm{~mm}$ ).

Wówczas uniwersalny zestaw kołowy przejeżdżałby przez serce zwrotnicy kolejowej tak samo niezawodnie, jak czyni to klasyczny kolejowy zestaw kołowy.

\subsubsection{Wnioski}

Uniwersalny zestaw kołowy, który byłby zdolny do przejazdu zarówno przez zwrotnicę kolejową jak i przez tramwajową, musiałby mieć koła, których wymiary poprzeczne byłyby takie, jak przedstawiono na rys. $2 \mathrm{z}$ uwzględnieniem dodatkowej warstwy materiału, a jego obrzeże byłoby identyczne $\mathrm{Z}$ obecnym obrzeżem koła tramwajowego.

Do tego we wszystkich zwrotnicach kolejowych na trasach, po których miałyby kursować tramkole, musiałyby zostać wymienione wszystkie kierownice zwrotnic na kierownice o wysokości $\mathrm{H}^{+10} \mathrm{~mm}$ ponad poziom główki szyny. To nie popsułoby przejezdności tych zwrotnic przez klasyczny tabor kolejowy, gdyż takie kierownice występują we Francji i po tych zwrotnicach jeździ bez przeszkód klasyczny tabor kolejowy wszystkich krajów, w tym również tabor polski. Nadto zarys odniesienia kolejowej skrajni kinematycznej stosowanej przez UIC dla lokomotyw i pojazdów trakcyjnych ma wysokość swej dolnej krawędzi równą $80 \mathrm{~mm}$ ponad główką szyny, a wysokość dolnej krawędzi zarysu odniesienia skrajni stosowanej dla wagonów wynosi $130 \mathrm{~mm}$ nad główką szyny, wobec czego wymiar $\mathrm{H}$ nie stanowiłby żadnej przeszkody dla przejeżdżającego taboru.

Ale w samym tramwaju, który miałby stać się tramkolem, dotychczasowy zarys odniesienia skrajni kinematycznej ma swą dolną krawędź położoną na wysokości $60 \mathrm{~mm}$ ponad główką szyny. Mogłaby zaistnieć kolizja części zawieszonych pod wózkiem tramwaju z kierownicami zwrotnic o wysokości H. Należałoby zatem przekonstruować wszelkie elementy wózka tramwajowego znajdujące się nisko nad główkami szyn (przekładnie zębate napędu głównego, tarcze hamulców tarczowych, maźnice itp.) na takie, które nie kolidowałyby ani z kierownicami zwrotnic o wysokości $H$, ani ze zmniejszonym w stosunku do obecnego odstępem wewnętrznych czół kół tramwaju $\left(\mathrm{a}_{\mathrm{kol}}\right.$ $=1360^{ \pm 1} \mathrm{~mm}$, wobec obecnie stosowanego $\mathrm{a}_{\text {tramw }}=$ $1385^{ \pm 1} \mathrm{~mm}$ ). Te przeróbki konstrukcji tramwaju mogą być bardzo trudne, a dla wagonów niskopodłogowych wręcz niemożliwe do wykonania.

Drugą możliwością jest zastosowanie zwrotnic kolejowych z zamykanym sercem na wszystkich trasach, po których miałyby jeździć tramkole. Zwrotnica $\mathrm{Z}$ zamykanym sercem nie potrzebuje kierownicy i nie posiada pustej przestrzeni w sercu.

Wtedy dla tramkolu wystarczającym byłoby obecnie stosowane zwykłe koło tramwajowe o szerokości f = $90^{ \pm 1} \mathrm{~mm}$. Zwrotnica taka byłaby również przejezdna dla taboru kolejowego bez żadnych przeszkód.

\section{LITERATURA}

[1] J. Dabrowski: „,Rozważania nad koncepcja napędu tramwajowego dwusystemowego $w$ warunkach polskich”. Technika Transportu Szynowego, Nr 9/1999. 
[2] W. Czyczula: „Koncepcja zintergrowanego systemu transportu szynowego dla Krakowa”. Technika Transportu Szynowego, Nr 9/1999.

[3] J. Wesolowski: „Pociagiem przez centrum Łodzi”. Technika Transportu Szynowego, $\mathrm{Nr}$ 9/1999.

[4] W. Czyczuła, A. Tulecki: „Budowa i badania eksploatacyjne pojazdu kolejowo-tramwajowego TRAMKOL 02”. Technika Transportu Szynowego, $\mathrm{Nr}$ 6/2000.

[5] PN-84/H-93421. Szyny normalnotorowe.

[6] Karta UIC 510-2. Pojazdy doczepne. Warunki dla stosowania kót o różnych średnicach $w$ układach biegowych różnego typu. Wydanie 4 z kwietnia $2004 r$.
[7] PN-91/K-88251. Zestawy kolowe taboru tramwajowego. Kontur bieżni kót elastycznych wagonów tramwajowych.

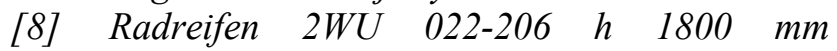
Achsabstand, rysunek niemiecki z r. 1993.

[9] PN-92/H-93440. Stal. Szyny tramwajowe $z$ rowkiem.

[10] Przepisy D1 - Przepisy techniczne utrzymania $i$ eksploatacji nawierzchni na liniach kolejowych normalnotorowych użytku publicznego, wprowadzone Zarzqdzeniem nr 47 Ministra Komunikacji z dn. 01.06.1982r.

[11] Karta UIC 505-1. Pojazdy kolejowe. Skrajnia pojazdów. 